\title{
VÝKLAD PRÁVNÍCH JEDNÁNÍ A INTERPRETACE SOUKROMOPRÁVNÍCH PŘEDPISÜ: CO MAJÍ SPOLEČNÉHO, ČÍM SE LIŠÍ A JAKÝ TO MÁ VÝZNAM?*
}

\author{
KAREL BERAN**
}

\begin{abstract}
The Interpretation of Legal Acts and the Interpretation of Private Law: What are Their Common Features, What Makes Them Different and What Significance Does It Have?

This paper aims to clarify what is the difference between the interpretation of legal acts (conduct) and the interpretation of provisions of private law legislation, and what is of the importance thereof in terms of unity and fragmentation of law as a system. First of all, the paper explains that comparing the interpretation of legal provisions with the interpretation of legal act is possible and it is not conceptually two completely different cases, even though we find different ways of interpretation in connection with what is being interpreted. The author concludes that, in the two above-mentioned cases, the use of interpretation methods results in completely different manners of interpretation. If linguistic, systematic and logical method of interpretation serves correctly as the starting point in the construction of law and these methods are followed by teleological interpretation, in the case of legal acts, the order is exactly the opposite. The basic method of interpreting legal acts is teleological, while systematic and logical interpretation can only serve to establish the intent followed by the person taking the act. The practical consequence of differentiating the methodology of interpretation is the view of law as a system that consists not only from general legal rules, but also from legal acts between individuals. However, although a legal act is formally described or understood as individual, it is necessary to differentiate legal act between two individuals and legal act affecting individually unspecified natural or juristic persons, as in the case of founding legal act, i.e. instrument of constitution of a juristic person. Such legal act must be understood substantivelly and not formally. Otherwise, it could result not in a systemic approach to law, but in its fragmentation, or antisystemic interpretation lacking rational justification.
\end{abstract}

Keywords: interpretation; methods of interpretation; private law; legal act (legal conduct); teleological interpretation; intent of the person taking an act; interpretation of a contract

Klíčová slova: interpretace, interpretační metody; soukromé právo; právní jednání; teleologický výklad; úmysl jednajícího; výklad smlouvy

DOI: $10.14712 / 23366478.2019 .20$

\footnotetext{
* Tento článek byl zpracován v rámci projektu Grantové agentury ČR reg. č. 19-10723S „Co současné právo sjednocuje a co jej fragmentarizuje z pohledu právní teorie a soudní praxe?“.

** Autor působí jako docent na katedře teorie práva a právních učení Právnické fakulty UK v Praze. Autor děkuje za připomínky a náměty k tomuto článku JUDr. Pavlu Ondřejkovi, Ph.D., jakož i dvěma anonymním recenzentům.
} 


\section{1. ÚVODEM}

Předmětem interpretace je jazykové vyjádření právní normy. To ale neznamená, že předmětem interpretace musí být jen norma obsažená v ustanovení právního předpisu, typicky zákona. Předmětem interpretace může být (a pravidelně také je) např. smlouva jakožto právní titul, který je důvodem vzniku subjektivního práva a povinnosti. Mezi obecnou právní normou obsaženou v textu zákona na straně jedné a individuálním právním titulem - „právním jednáním“ - na straně opačné se však v recentní české právní teorii striktně odlišuje. Jestliže tak v občanském zákoníku nacházíme svébytná výkladová ustanovení, která se týkají výkladu právních jednání, obvykle si nikdo neklade otázku, co mají společného a čím se liší od interpretačních ustanovení, která se vztahují $\mathrm{k}$ právním předpisům. Lze však o výkladu právního jednání vůbec uvažovat v obdobném smyslu jako o interpretaci práva a je vůbec na místě srovnávat „právní jednání“ na straně jedné s ustanovením zákona na straně opačné? Ustanovení zákona přece na rozdíl od právního jednání obsahuje obecnou právní normu, zatímco právní jednání pouze individuální právní povinnost. Má tedy právní jednání s ustanovením zákona vůbec něco společného?

Na to, co má právní jednání společného s ustanovením zákona, poukázala ryzí nauka právní. Jak právní jednání, tak zákon totiž podle normativistů obsahují právní (tedy státní mocí vynutitelnou) povinnost, a tedy i právní normu. Podle Weyra totiž i ,soukromá smlouva, která v daném právě př́kladě vyvolává podmiňujici skutkovou podstatu, jeví se nesporně jako norma. Normotvůrci jsou tu smluvni strany, jako při rozsudku je normotvi̊rcem soudce a při zákonu zákonodárce (parlament, panovník atd.). Než nejen skutečnost, že zápůjčka byla poskytnuta, která, jako prostý děj ve světě vnějším, nemǐže se jeviti jako norma, nýbrž i okolnost, že touto skutečností vzniká povinnost (smluvní), tedy norma, lze vzhledem k př́padné pozdějši normě rozsudeční, v niž ona smluvni povinnost jest znova deklarována, jakož i vzhledem $k$ nadř̀zené obecné normě o půjčkách, zápiojjčkách atd., považovati za skutkovou podstatu, která jest nezbytným předpokladem konkretisace abstraktni (obecné) normy v konkrétni, jinými slovy: rozsudek, vyslovujicí (stanovicí) povinnost žalovaného A, aby vrátil zapůjčenou částku panu B, může býti vydán jen tehdy, byla-li zde ona podmiňujicí skutková podstata, t.j. byla-li zápioijčka panu $B$ skutečně poskytnuta. Jen za této podminky mi̊že dojiti ke kladné aplikaci, t.j. konkretisaci nadřizené obecné normy o zápůjčkách."1

$\mathrm{Z}$ dnešního pohledu můžeme rozdíl spatřovat $\mathrm{v}$ tom, že zákon by měl obsahovat obecnou právní normu, zatímco právní jednání pouze individuální právní povinnost. Normativisté však tvrdili, že i v př́padě právního jednání se jedná o normu, nikoliv však normu obecnou, nýbrž individuální a svým obsahem konkrétní. Pojmově se však jedná o normu, která je vynutitelná, nebot' vychází z jednoho normového ohniska, ke kterému se lze vrátit při odpovědi na otázku, podle čeho byla dotyčná norma vydána. Smluvní povinnosti jsou vynutitelné, nebot' vznikají na základě zákona - občanského zákoníku. Občanský zákoník vznikl (byl vydán) na základě ústavy, čímž se již téměř dostáváme k základní normě, kterou můžeme zjednodušeně řečeno ztotožnit s ústavou, nebo o tro-

WEYR, F. Teorie práva. Brno - Praha: Orbis, 1936, s. 129-130. 
chu složitěji s normou, která nad touto ústavou stojí a opravňuje prvního ústavodárce k jejímu vydání.

Z toho plyne, že i výklad právních jednání lze považovat za interpretaci právních norem, které tvoří součást práva soukromého. Při odpovědi na otázku, čím se liší výklad právních jednání od interpretace právních předpisů, je tedy třeba se nejprve zabývat tím, v čem spočívají specifika interpretace soukromého práva, a v návaznosti na to odpovědět na otázky:

1. Jakým způsobem se mají vykládat zákonná ustanovení soukromého práva?

2. Jakým způsobem se mají vykládat právní jednání?

V obou těchto případech je třeba se především zamyslet nad otázkou, v jakém pořadí se mají interpretační metody používat a jaký význam je třeba jednotlivým metodám přisoudit, tj. která $\mathrm{z}$ metod by měla mít přednost?

\section{V ČEM SPOČÍVAJÍ SPECIFIKA INTERPRETACE SOUKROMÉHO PRÁVA?}

Právní norma je základním prvkem právního řádu. Jak právo soukromé, tak právo veřejné je tak tvořeno právními normami, jejichž pojetí i struktura je v obou př́padech stejná. ${ }^{2}$ Klade se proto otázka, zda mohou vůbec existovat nějaké zvláštní interpretační metody nebo zvláštní způsoby jejich použití, které by se snad mohly či měly vztahovat pouze na právní normy obsažené v soukromém právu. Není to snad tak, že interpretace se vždy vztahuje k právní normě a metody, které se přitom používají, musí být stejné $\mathrm{v}$ případě každé právní normy bez ohledu na to, zdali se nachází v soukromém či veřejném právu?

Odpověd' na tuto otázku souvisí s dvojím možným přístupem k interpretaci. Interpretaci lze totiž chápat bud' jako teoretickou disciplínu a vědeckou metodu poznání právní normy, nebo jako závazný postup, kterým zákon stanovuje, jak se má právo vykládat, a tedy i aplikovat. Z toho plyne, že interpretační metody sice zákonem upraveny být mohou, ale nemusí. Přestože však upraveny jsou, resp. býti mohou, neznamená to, že metodologii interpretace práva lze normativně stanovit právním předpisem, a vyloučit tak vědeckou diskuzi na toto téma. I v takovém př́ípadě je právní věda ve vztahu k platnému právu autonomní a může, ba dokonce by měla, rozvíjet a vysvětlovat právní metodologii, aniž by byla vázána interpretačními direktivami, které jsou stanoveny v platném právu. Na druhou stranu to ale neznamená, že právní teorie může přehlížet pravidla interpretace obsažená v platném právu. Naopak, jejím úkolem je tato pravidla reflektovat a kriticky přezkoumávat. $Z$ toho také plyne, že pokud interpretační pravidla v platném právu vůbec obsažena nejsou, nic se nestane, nebot' jsou předmětem zájmu právní teorie a doktríny.

2 V této souvislosti je však třeba odlišovat mezi interpretací jazykového znění právní normy a interpretací právních principů. Zejména $v$ př́ípadě ústavního práva přichází v úvahu výklad, jehož předmětem nejsou jen normy chování, nýbrž také velmi často kompetenční a imperfektní právní normy, jakož i právní principy. Z toho důvodu lze uvažovat o tom, že výklad ústavního práva může být specifický oproti výkladu běžného práva, které především obsahuje normy chování. K tomu srovnej: HOLLÄNDER, P. Ústavněprávní argumentace: ohlédnuti po deseti letech Ústavního soudu. Praha: Linde, 2003, s. 55. 
Minulá a současná právní úprava v České republice dokazuje, že oba dva tyto př́istupy jsou možné. Všeobecný občanský zákoník, který na území současné ČR platil od roku 1811 až do roku 1950, výkladová pravidla ${ }^{3}$ obsahoval. Od roku 1950 až do roku 2014 byly v Československu a později též i v samostatné České republice metody právní interpretace ponechány právní teorii a v občanském ani jiném kodexu nebylo obdobné ustanovení obsaženo. Zásadní změna však nastala v roce $2014 \mathrm{~s}$ účinností nového občanského zákoníku. Jazykové vyjádření § 2 občanského zákoníku 4 ukazuje na to, že zdrojem inspirace pro něj byl (kromě jiného také) všeobecný občanský zákoník. Jak ale upozornila Katarzyna Žák Krzyžanková ,ideově obě tyto kodifikace vyrůstaji ze zcela odlišných představ. Osvícenství - zjednodušeně ř rečeno - chtělo svázat soudce psaným textem, nová tuzemská úprava vybizi soudce k aktivnímu posuzování interpretačnich závěru a jejich dopadi̊ na život jednotlivců..." "5 Další důležitý rozdíl spočívá v postavení, které v právním řádu zaujímal všeobecný občanský zákoník a které zaujímá v právu ČR občanský zákoník. Podle Jana Tryzny však interpretační pravidla ve všeobecném občanském zákoníku „byla chápána spiše jako návod, jak přistupovat k zákonu, nikoliv jako jednoznačný závazný př́kaz k určitému postupu při interpretaci. Bylo tomu tak proto, že samotná tato pravidla byla objektem interpretace, což stupeň závaznosti jejich obsahu snižovalo." "Právě tím, že český občanský zákoník - po vzoru všeobecného občanského zákoníku z roku 1811 - obsahuje zvláštní ustanovení, která se týkají interpretace ustanovení zákona, se však podstatně odlišuje od všech ostatních kodexů v ČR, kde žádná interpretační ustanovení nenacházíme.

Specifikum interpretace soukromého práva v ČR tedy spočívá $\mathrm{v}$ tom, že na rozdíl od veřejného práva, zákon stanoví způsob interpretace zákonných ustanovení soukromého práva, tj. především pořadí interpretačních metod.

3 Výklad

§ 6 Zákonu při používání nesmí býti dáván jinaký smysl, než jaký vychází z vlastního smyslu slov v jejich souvislosti a z jasného úmyslu zákonodárcova.

§ 7 Nelze-li právní př́ípad rozhodnouti ani podle slov ani z přirozeného smyslu zákona, jest hleděti k podobným př́ípadům v zákonech zřejmě rozhodnutým, a k důvodům jiných, $\mathrm{s}$ tím př́ibuzných zákonů. Zůstane-li právní príípad ještě pochybný, musí býti rozhodnut podle přirozených zásad právních, se zřetelem k okolnostem pečlivě shrnutým a zrale uváženým.

$\S 8$ Jen zákonodárci náleži moc vyložiti zákon způsobem obecně závazným. Takovým projevem nutno se říditi ve všech právních př́padech dosud nerozhodnutých, pokud zákonodárce nepřipojil, že jeho projev nemá býti vztahován na rozhodování takových právních př́padů, jejichž předmětem jsou konání učiněná a práva uplatňovaná před oním projevem.

4 (1) Každé ustanovení soukromého práva lze vykládat jenom ve shodě s Listinou základních práv a svobod a ústavním pořádkem vủbec, se zásadami, na nichž spočívá tento zákon, jakož i s trvalým zřetelem k hodnotám, které se tím chrání. Rozejde-li se výklad jednotlivého ustanovení pouze podle jeho slov s tímto príkazem, musí mu ustoupit.

(2) Zákonnému ustanovení nelze přikládat jiný význam, než jaký plyne z vlastního smyslu slov v jejich vzájemné souvislosti a z jasného úmyslu zákonodárce; nikdo se však nesmí dovolávat slov právního předpisu proti jeho smyslu.

(3) Výklad a použití právního předpisu nesmí být v rozporu s dobrými mravy a nesmí vést ke krutosti nebo bezohlednosti urážející obyčejné lidské cítění.

5 ŽÁK KRZYŽANKOVÁ, K. Quid iuris? (Deskriptivni teorie právní interpretace a argumentace), s. 64. [online]. 2015 [cit. 25. 7. 2018]. Dostupné na: https://is.cuni.cz/webapps/zzp/detail/53575.

6 TRYZNA, J. Garance právní jistoty z hlediska metodologie interpretace práva předvídané navrhovaným občanským zákoníkem. In: HULMÁK, M. - BEZOUŠKA, P. - TRYZNA, J. Stará judikatura ve světle nových zákonů. Olomouc: Iuridicum Olomoucense, 2012. 


\section{JAKÝM ZPU゚SOBEM SE MAJÍ VYKLÁDAT ZÁKONNÁ USTANOVENÍ SOUKROMÉHO PRÁVA?}

\subsection{JAKÉM POŘADÍ SE MAJÍ VYKLÁDAT PRÁVNÍ NORMY OBSAŽENÉ V ZÁKONNÝCH USTANOVENÍCH SOUKROMÉHO PRÁVA?}

Jaké interpretační metody český zákonodárce předpokládal a stejně tak $\mathrm{v}$ jakém pořadí se mají tyto metody použít, lze vyčíst především z $\S 2$ občanského zákoníku. ${ }^{7}$ Domnívám se, že východisko by měl představovat jeho druhý odstavec. Jestliže je v něm totiž uvedeno, že ,zákonnému ustanovení nelze přikládat jiný význam, než jaký plyne z vlastního smyslu slov v jejich vzájemné souvislosti“", potom $\mathrm{z}$ toho po mém soudu plyne, že za základní interpretační metodu je třeba považovat výklad jazykový (gramatický). „Vzájemná souvislost slov“ pak vyjadřuje nutnost použití výkladu systematického, jakož po mém soudu i logického. ${ }^{8}$ Zmiňuje-li se dotyčný odstavec o jasném úmyslu zákonodárce, potom se tím myslí historický výklad směřující k účelu právní úpravy, který onen historický zákonodárce v souladu s úmyslem vyjádřeným v důvodové zprávě sledoval. Teprve poslední část věty „nikdo se však nesmí dovolávat slov právního předpisu proti jeho smyslu" míní teleologickou metodu výkladu. Tím se však již dostáváme k otázce, na niž se pomocí teleologického výkladu odpovídá, tj. jakého cíle má právní úprava dosáhnout a jaké hodnoty jsou touto úpravou chráněny.

Chráněnými hodnotami má podle $\S 3$ odst. 1 občanský zákoník na mysli „,di̊stojnost a svobodu člověka, i jeho pririrozené právo brát se o vlastni štěstí a štěstí jeho rodiny nebo lidí jemu blízkých takovým způsobem, jenž nepůsobí bezdi̊vodně újmu druhým“". Proto také podle $\S 2$ odst. 3 občanského zákoníku nesmí výklad a použití právního předpisu být „v rozporu s dobrými mravy a nesmí vést ke krutosti nebo bezohlednosti urážejíci obyčejné lidské citěni“". Při hledání hodnot, které občanské právo chrání, se však nelze omezovat pouze na předpisy soukromého práva, nebot' podle $\S 2$ odst. 1 občanského zákoníku „každé ustanovení soukromého práva lze vykládat jenom ve shodè s Listinou základnich práv a svobod a ústavním pořádkem vůbec...". Chráněné hodnoty, které normy občanského práva vyjadřují, tedy nenalézáme jen v občanském právu samotném, nýbrž i v právu ústavním. ${ }^{9}$ Jak z $§ 2$, tak z $§ 3$ je patrné, že zdůrazňují význam hodnot, které občanský zákoník chrání. To ovšem neznamená, že by mělo být ignorováno jazykové vyjádření zákonného ustanovení. Naopak. Z poslední věty § 2 odst. 1 občanského zákoníku ,rozejde-li se výklad jednotlivého ustanovení pouze podle jeho slov s tímto príkazem, musí mu ustoupit" po mém soudu plyne, že dříve než přistoupíme k teleolo-

7 Viz poznámka pod čarou č. 5.

8 Předpokladem totiž je, že logický výklad budeme chápat jako samostatnou metodu výkladu. V této souvislosti odkazuji zejména na Jana Wintra, který logický výklad jako samostatnou kategorii nechápe, a navazuje tak na kritiku Františka Cvrčka, která se vztahovala k ,právní logice“. K tomu srovnej WINTR, J. Metody a zásady interpretace práva. Praha: Auditorium, 2013, s. 26; CVRČEK, F. Kritické poznámky k výuce interpretace právních textů. In: GERLOCH, A. - MARŠÁLEK, P. (ed.). Problémy interpretace a argumentace $v$ soudobé právni teorii a právni praxi: sborník př́spěvkỉ z védeckého kolokvia kateder teorie práva právnických fakult České republiky (Milovy 19.-20. 6. 2002). Praha: Eurolex Bohemia, 2003.

$9 \mathrm{~K}$ funkcím ústavních hodnot $\mathrm{v}$ českém soukromém právu viz ONDŘEJEK, P. A Structural Approach to the Effects of Fundamental Rights on Legal Transactions in Private Law. European Constitutional Law Review. Cambridge University Press, 2017, č. 2, s. 297 a násl. 
gickému výkladu, jehož předmětem není jen samotný text právního předpisu, je třeba použít výklad podle jeho slov, tj. jazykový, logický a systematický. Teprve tehdy, když se výklad podle slov rozchází s výkladem založeným na hodnotách, musí mu ustoupit.

Mám tedy za to, že z $§ 2$ lze vyvodit následující pořadí použití interpretačních metod:

1. jazykový

2. systematický (a logický)

3. historický

4. teleologický.

$\mathrm{Z}$ toho plyne, že teleologický výklad by měl následovat až jako poslední $\mathrm{v}$ př́ípadě, kdy jsou všechny předchozí metody vyčerpány. To ostatně tvrdí i zastánce teleologického výkladu Jan Wintr, podle kterého „má text zákona pro interpretaci značný význam. Je tomu tak nejen proto, že i historické a teleologické úvahy museji začí od textu zákona."10 Jiná a složitější otázka však je, jaký je význam jednotlivých interpretačních metod a které by měly mít případně vyšší váhu.

\subsection{JAKÝ VÝZNAM MAJÍ MÍT JEDNOTLIVÉ METODY INTERPRETACE?}

Při řešení otázky, jaký význam mají mít jednotlivé metody interpretace, nepanuje v české právní doktríně jednota. To platí, nejen pokud jde o teoretický př́stup k metodám interpretace, nýbrž také pokud jde závaznost postupu při interpretaci, která plyne (resp. by měla plynout) z výkladových pravidel obsažených v občanském zákoníku. $V$ obou těchto príípadech jde $\mathrm{v}$ zásadě o to, zda by větší váhu měly mít výsledky interpretace, ke kterým dospějeme na základě jazykového a systematického výkladu (textualismus), nebo naopak výsledky, ke kterým dospějeme na základě historického či teleologického výkladu (intencionalismus). K autorům, kteří v České republice upřednostňují psaný text, a tedy i textualistický výklad, náleží zejména Aleš Gerloch nebo Jan Tryzna, naopak k autorům, kteří preferují účel, jenž by právní norma měla sledovat, náleží Filip Melzer ${ }^{11}$ nebo Jan Wintr ${ }^{12}$.

Jan Wintr vychází z klasické čtveřice interpretačních metod, kterou ostatně také nachází v $§ 2$ občanského zákoníku, který vykládá následujícím způsobem: „Snadno $v$ tomto ustanovení ( $t$. $\$ 2$ o.z. pozn. autora) nalezneme pokyn $k$ výkladu jazykovému (, význam, [...] jaký plyne z vlastního smyslu slov v jejich vzájemné souvislosti '), systematickému (,ve shodè s Listinou základnich práv a svobod a ústavním pořádkem vůbec, se zásadami, na nichž spočivá tento zákon '), historickému (,z jasného úmyslu zákonodárcova ') i teleologickému (,s trvalým zrèetelem k hodnotám, které se tím chráni' , a celý odstavec 3)."13 Oporu pro větší význam teleologického výkladu Jan Wintr nachází ostatně mimo jiné př́mo v $§ 2$ občanského zákoníku, když říká: „proti textualismu hovoři

\footnotetext{
$10 \mathrm{~K}$ tomu viz např.: „Protože soudce je vázán zákonem a ve sbirce zákonů je vyhlašován jen text zákona, měl by podle mého názoru mít jazykový (a s ním souvisejicí systematický) výklad přinejmenším prima facie přednost před historickým a teleologickým výkladem." WINTR, c. d., s. 186.

11 MELZER, F. Metodologie nalézáni práva: úvod do právní argumentace. 2. vyd. Praha: C. H. Beck, 2011.

12 WINTR, J. Metody a zásady interpretace práva. Praha: Auditorium, 2013.

13 WINTR, c. d., s. 26.
} 
př́liš silné argumenty a dnes se k němu nehlásí ani judikatura (srov. kapitolu 7.1), ani zákonodárce (srov. § 2 nového občanského zákoníku)“. ${ }^{14} \mathrm{Na}$ základě těchto argumentů pak Jan Wintr dospívá k tzv. pravidlům přednosti, která, pokud jde o vztah k textu a účelu právní normy, formuluje takto:

„Zákaz opomíjení účelu a smyslu právní úpravy. I když je text zákona jednoznačný, nelze jej aplikovat mechanicky bez zvážení účelu a smyslu právní úpravy. Je třeba usilovat o harmonizaci interpretačních výsledků, protože jen řešení odstraňující rozpory mezi jazykovým, systematickým a teleologickým výkladem je skutečně presvědčivé.

Přednost teleologického výkladu před formálně systematickým výkladem u víceznačného textu zákona. Při poměřování totiž převáži hodnoty nesené teleologickým výkladem nad presumpcí racionálního zákonodárce a s ní související právní jistotou vycházející jen ze zkušenosti s koncipováním právních textů. To platí zejména u zásad výše řazených pod principy vyloučení redundance a systematiky zákonodárství."15

$\mathrm{V}$ díle Filipa Melzera především nacházíme poněkud odlišnou klasifikaci interpretačních metod. Ta vychází z tzv. výkladového cíle, kterým je třeba rozumět to, ,co má být pomocí výkladu zjištěno“. ${ }^{16}$ Filip Melzer dělí výkladové cíle do dvojic podle dvou hledisek. Prvním je dělení na subjektivní a objektivní výkladový cíl. ${ }^{17}$ Východiskem pro toto rozlišení je zjištění toho, na koho má daný text působit. Jestliže pátráme po tom, jaký význam přikládal textu jeho autor, pak se jedná o subjektivní výkladový cíl. Naopak pokud nalézáme to, jak má text chápat jeho př́jemce, jde o objektivní výkladový cíl. Podle druhého dělení rozlišujeme výkladové cíle na historické a recentní. ${ }^{18}$ U tohoto dělení je hlediskem plynutí času. Historický výkladový cíl je takový, jehož interpretace se vztahuje k datu vydání textu. Naproti tomu recentní výkladový cíl znamená, že se výklad vztahuje právě k datu jeho interpretace. Podstatné a více patrné je toto dělení hlavně u objektivního výkladového cíle. Je jistě jiné chápání textu adresátem v době jeho vydání na rozdíl od doby jeho aplikace. Na základě vzájemné kombinace těchto cílů Filip Melzer rozlišuje čtyři základní výkladové cíle. Jsou jimi historický subjektivní výkladový cíl, recentní subjektivní výkladový cíl, recentní objektivní výkladový cíl a historický objektivní výkladový cíl. ${ }^{19} \mathrm{~K}$ možnosti aplikace uvedených výkladových cílů je nutné určení důvodů jejich legitimity, které musí být zřejmé již ze základních principů právního řádu. ${ }^{20}$ Po zhodnocení všech těchto čtyř výkladových cílů dospívá Melzer k závěru, že „v našem právním řádu se vyskytují legitimizační důvody pouze pro dva z uvedených cílù. Jsou jimi subjektivně historický a objektivně recentní výkladový cíl."21 Způsoby, jakými lze dospět k určitému výkladovému cíli, se nazývají metody výkladu a každá metoda má své argumenty, pomocí nichž lze určitého

\footnotetext{
4 WINTR, c. d., s. 186.

WINTR, c. d., s. 207.

6 MELZER, c. d., s. 80.

MELZER, c. d., s. 81.

8 MELZER, c. d., s. 81.

19 K tomu srovnej též: KRAMER, E. A. Juristische Methodenlehre. 4. Auflage. Bern: Stämpfli Verlag, 2013; či BYDLINSKI, F. Grundzüge der juristischen Methodenlehre. 2. überarb. Auflage. Wien: UTB, Facultas, WUV Universitätsverlag, 2012.

20 MELZER, c. d., s. 81-82.

21 MELZER, c. d., s. 86.
} 
výkladového cíle dosáhnout. Své výkladové metody mají i oba výkladové cíle, které v českém právním řádu existují legitimně. Pro subjektivně historický výkladový cíl je jím výklad subjektivně historický a pro objektivně recentní výkladový cíl jsou jimi výklad formálně systematický a objektivně teleologický. ${ }^{22}$

Opačný pohled na tuto otázku reprezentuje stanovisko Aleše Gerlocha a Jana Tryzny. ${ }^{23}$ Za jejich východisko lze považovat rozlišování interpretačních metod Aleše Gerlocha na standardní a nadstandardní. Standardní metody, tj. výklad jazykový, systematický a logický, by měly být podle jejich názoru používány nejen jako první, ale měly by mít při interpretaci vyšší váhu oproti metodám nadstandardním, které zahrnují výklad historický, teleologický a komparativní. Podle Aleše Gerlocha je pro všechny tři „,nadstandardní“ metody výkladu společná argumentace e ratione legis - argumentace ,rozumem“ zákona, tj. jeho smyslem, duchem, účelem. „Z hlediska legality je důležité, že argumentační závěry takto zjištěné nemohou obstát, jsou-li ve zjevném rozporu s textem (literou) zákona, resp. mezinárodní smlouvy, a s interpretačními výsledky dosaženými standardními metodami." 24

Spor o to, co by mělo mít při výkladu větší váhu, se projevuje také (a možná především) v tom, co se vyvozuje z $§ 2$ občanského zákoníku, jenž stanovuje, jak postupovat při interpretaci soukromého práva. Zjednodušeně řečeno lze konstatovat, že na jedné straně spektra se opět nachází Jan Wintr spolu s Filipem Melzerem, kteří považují za určující poslední část věty $\S 2$ odst. 2, která říká „nikdo se však nesmí dovolávat slov právního predpisu proti jeho smyslu“. Právě tato věta představuje důležitou zákonnou oporu, proč by teleologický výklad preferující ,,smysl“ před jazykovým vyjádřením měl mít podle jejich názoru přednost. V obdobném duchu se ostatně vyjadřuje i důvodová zpráva $\mathrm{k} \S 2$ odst. 2 občanského zákoníku, ve které se lze dočíst: „,navržené ustanovení zdůrazňuje, že zákon nelze vykládat jen z jeho slov, ale je nutno přihližet především k jeho smyslu. Zákonodárce si musí být védom, že slova zákona nemusí vždy dokonale vyjádřit jeho úmysl, a proto ukládá soudci, aby tato slova zvažoval, poměroval je právními principy a zásadami, nespokojil se jen s gramatickým výkladem a hledal skutečný obsah zákona."

Podle Jana Tryzny, který je hlavním reprezentantem opačného názoru, však „,vysvětlení záměru autorů obsažené v di̛vodové zprávě zjevně nekoresponduje s formulací ustanovení 2 odst. 2. Podle důvodové zprávy má soudce vzít v úvahu, že zákonodárce nemusi být vždy schopen svi̊j úmysl výstižně vyjádřit, tudǐz soudce má hledat, skutečný obsah zákona:. ... Účel zákona lze dovodit z jeho slovního vyjádření, z obsahu zákona, nebot'v ničem jiném nelze oporu pro hledání smyslu zákona nalézt. Oproti tomu úmysl zákonodárce (záměr sledovaný zákonodárcem) lze hledat i mimo vyjádření tohoto

22 MELZER, c. d., s. 86.

23 K tomu srovnej zejména kapitolu: GERLOCH, A. - TRYZNA, J. Úvodní teze metodologie interpretace práva. In: GERLOCH, A. - TRYZNA, J. - WINTR, J. (ed.). Metodologie interpretace práva a právní jistota. Plzeň: Vydavatelství a nakladatelství Aleš Čeněk, 2012; nebo GERLOCH, A. - TRYZNA, J. Závaznost právních textů při interpretaci a aplikaci práva soudy a argumentace lege artis. In: GERLOCH, A. TOMÁS̆EK, M. Nové jevy v právu na počátku 21. století. Praha: Karolinum, 2010, s. 25.

24 GERLOCH, A. Teorie práva. 7. aktualizované vydání. Plzeň: Vydavatelství a nakladatelství Aleš Čeněk, 2017, s. 147. 
úmyslu v zákoně. Takový závěr plyne i z textu § 2 odst. 2, který vedle sebe klade, vlastní smysl slov v jejich vzájemné souvislosti “ a ,jasný úmysl zákonodárce“."25

Podle Jana Tryzny je zdrojem nejasností právě ta část věty, podle které se nikdo nesmí dovolávat slov právního předpisu proti jeho smyslu. Podle něj je totiž ,matoucí představa o existenci, skutečného obsahu zákona', jenž dle autorů může být odlišný jak od slov zákona, tak od úmyslu zákonodárce“. Zjednodušeně řečeno tak Jan Tryzna tvrdí, že smysl zákona plyne z jeho jazykového vyjádření, poprrípadě ve spojení s úmyslem zákonodárce, který k vyjádření svého úmyslu ostatně používá především slova, kterými svůj úmysl vyjadřuje. Z toho plyne, že dotyčné ustanovení je ve skutečnosti rozporuplné, nebot' umožňuje výklad, který smysl právního předpisu hledá v jeho slovech (textualismus), nebo v jeho účelu, který nemusí korespondovat s jeho slovy (intenacionalismus).

Výše popsaný střet těchto dvou názorových proudů je jen praktickou demonstrací jevu, který nedávno reflektoval Miloš Večeřa, když konstatoval: „Pro proces interpretace a aplikace práva se v tomto směru jeví jako zvlášt’ závažná postmoderní relativizace pravdy, jež je vázána na určitá pravidla, mezi nimiž lze volit. Postmoderna tak prináší uznání více možností řě̌ení, která jsou přitom stejně vhodná a adekvátní a jen těžko se určuje, či pravda nebo názor je ,lepši “ a či , horší'. Fakt odlišných právních prostorů a konec chápání práva jako objektivní reality pak znamená, že právo není výrazem jednoznačného př́kazu jedné nezpochybnitelné autority (zákonodárce), ale odvisí od výsledku diskurzivního procesu. Interpretační a aplikační proces práva tak nerezultuje v jeden správný výsledek. Realita práva je diskurzivním výsledkem podnětů účastníki̊ diskurzu disponujících odlišnou společenskou mocí. Právo je definováno nikoliv svým textem, ale svým významem, který je nalézán v procesu neustálé reinterpretace právním a společenským diskurzem. Účastníci diskurzu přitom mají odlišnou sílu a schopnosti přispět $k$ výsledku diskurzu." 26

$\mathrm{V}$ praktické rovině, tj. pokud jde o výklad pravidel regulujících interpretaci, s tím souzní vyjádření Katarzyny Žák Krzyžankové, která připomíná, že tato pravidla jsou „součástí normativního právního textu, a proto jako taková podléhají výkladu, tj. jsou objektem interpretace. Jen stěži lze proto v této chvíli predvídat, jak budou v praxi vykládána. Již nyní se totiž jednotliví predstavitelé právni doktríny rozcházejí v názoru na to, jak rozumět předmětným ustanovením NOZ.“27

Postmoderní skepse k tomu, jak rozhodnout a které řešení je vlastně správné, však těžko může představovat praktické vodítko, jak v konkrétním případě rozhodnout a k jakému interpretačnímu závěru se přiklonit. Pokud však má rozhodnutí posilovat právní jistotu adresátů práva, je podle mého názoru potřeba interpretovat podobné právní problémy podobně, tedy s využitím stejného postupu, pořadí interpretačních metod a zhod-

25 TRYZNA, J. Garance právní jistoty z hlediska metodologie interpretace práva předvídané navrhovaným občanským zákoníkem. In: HULMÁK, M. - BEZOUŠKA, P. - TRYZNA, J. Stará judikatura ve světle nových zákonů. Olomouc: Iuridicum Olomoucense, 2012, s. 77.

26 VEČĚ̌A, M. Soudcovská tvorba práva v kontextu postmoderny. In: VEČEŘA, M. - HURDÍK, J. - HAPLA, M. a kol. Nové trendy v soudcovské tvorbě práva. 1. vyd. Brno: Masarykova univerzita, 2015, 343 s. Spisy Právnické fakulty Masarykovy univerzity, řada teoretická, Edice Scientia, č. 541, s. 72.

27 ŽÁK KRZYŽANKOVÁ, c. d., s. 66. 
nocení jejich významu při vzájemném konfliktu. Proto považuji za správné přiklonit se $\mathrm{k}$ tomu či onomu názorovému proudu a předložit pro to své argumenty.

K výkladu, který preferuje text zákona před jeho smyslem, se přikláním i já. Skutečnost, že standardní metody by měly mít větší význam, plyne po mém soudu mimo jiné i z toho, že jsou používány pro výklad tzv. primárního objektu interpretace, kterým je text, z něhož poznáváme právní normu. Nadstandardní metody interpretace přicházejí naopak v úvahu teprve v okamžiku, kdy je interpretován nejen text, ale i hodnoty za textem stojící, tedy sekundární objekt. K interpretaci sekundárního objektů však můžeme přistoupit pouze výjimečně při tzv. obtížných př́ipadech. ${ }^{28} \mathrm{~K}$ řešení obtížných př́padů by však nemělo docházet u všech soudů, tj. u té nejnižší instance, nýbrž naopak u soudů instance nejvyšší, př́ípadně u soudu ústavního. Při aplikaci práva v těchto obtížných př́ípadech tak není důležité jen zjištění skutkového stavu a jeho subsumpce pod př́slušnou právní normu, nýbrž zejména řešení právních otázek. $V$ těchto př́ípadech se totiž nerozhoduje pouze na základě právních norem, nýbrž zejména též na základě hodnot a principů, které stojí v základu normativní regulace. Proto také, při aplikaci práva $v$ těchto obtížných př́padech, hraje zásadní úlohu princip proporcionality založený na poměřování kolidujících principů, případně základních práv a veřejných zájmů. 29

Ostatně jak jinak než pomocí principu proporcionality lze vyložit $\S 2$ odst. 3 občanského zákoníku, podle kterého jsou nejzazším kritériem akceptovatelnosti, ale i aplikovatelnosti určitého interpretačního závěru „,dobré mravy“ a „obyčejné lidské cítěni“", které mají zabránit vyslovování a použití „krutých“a „bezohledných“ výkladů soukromoprávních norem $\mathrm{v}$ jednotlivých př́padech. Plně v této souvislosti souhlasím s Katarzynou Žák Krzyžankovou, že je tím ,dán značný prostor pro úvahu rozhodovacích orgánů, přičemž je nasnadě, že se tímto - alespoň potenciálně - otevírá prostor právní nejistotě a nepredvídatelnosti práva, protože obyčejné lidské citění je jen stěži objektivně uchopitelné a definovatelné..."30

Zároveň je však třeba připustit, že pokud jde o interpretaci soukromého práva, bude mít teleologický výklad zásadní význam při řešení otázky, zda se vůbec na dotyčný právní př́ípad bude vztahovat právní úprava obsažená v občanském zákoníku (případně jiných soukromoprávních předpisech), nebo zda se lze od této úpravy odchýlit smluvním ujednáním. Důvodem proto je možnost, aby si strany smlouvou ujednaly odchylnou právní úpravu od zákona v souladu s $§ 1$ odst. 2 občanského zákoníku, který stanoví: „Nezakazuje-li to zákon výslovně, mohou si osoby ujednat práva a povinnosti odchylně od zákona; zakázána jsou ujednání porušujicí dobré mravy, veřejný porádek nebo právo týkajici se postaveni osob, včetně práva na ochranu osobnosti.“

Jestliže však smluvní strany svým ujednáním vyloučí aplikaci ustanovení zákona, potom to nebude zákon, který bude interpretován, nýbrž právní jednání, a pro právní jednání - jak bude ještě ukázáno - platí zcela jiné pořadí interpretačních metod.

$28 \mathrm{~K}$ tomu srovnej BERAN, K. Výklad (interpretace) norem občanského práva. In: DVOŘÁK, J. ŠVESTKA, J. - ZUKLÍNOVÁ, M. Občanské právo hmotné. 1. vyd. Praha: Wolters Kluwer ČR, 2013, s. 149.

29 ONDŘEJEK, P. Princip proporcionality a jeho role při interpretaci základních práv a svobod. Praha: Leges, 2012.

30 ŽÁK KRZYŽANKOVÁ, K. Právní interpretace - mezi vysvětlováním a rozuměním. Praha: Wolters Kluwer ČR, 2019, s. 64. 
Odpověd’ na otázku, kdy si osoby mohou autonomně ujednat vlastní právní úpravu, nemusí být jednoznačná. Pokud totiž zákon neobsahuje takový výslovný zákaz, potom je třeba přistoupit k úvaze, zdali by takové ujednání vedlo $\mathrm{k}$ porušení dobrých mraviơ, veřejného porádku nebo práva týkajícího se postaveni osob. Takovou úvahu však nelze učinit jinak než na základě teleologické interpretace. V tomto smyslu - v souvislosti s př́padnou autonomní právní úpravou na základě zásadně dispozitivního charakteru soukromého práva - lze uvažovat o prioritě teleologické metody interpretace před ostatními interpretačními metodami.

\section{JAKÝM ZPŮSOBEM SE MAJÍ VYKLÁDAT PRÁVNÍ JEDNÁNÍ?}

Právní jednání je třeba podle platného českého občanského zákoníku považovat za právní titul, tj. druh právní skutečnosti, která je důvodem vzniku subjektivních práv a povinností. Právní jednání tak v sobě zahrnuje dvoustranné a vícestranné právní jednání (tj. smlouvy), avšak i jednostranné právní jednání (např. testament). Již z toho plyne, že právní jednání - na rozdíl od ustanovení zákona - nemusí být vždy vyjádřeno jen slovy. Vždyt' přece často, ba dokonce většinou, dochází k uzavírání smluv jinak než verbálně, či dokonce písemně. Ten, kdo nastupuje do tramvaje, si ani nemusí být vědom toho, že právně jedná a uzavírá smlouvu o přepravě. Již z toho plyne, že pokud je předmětem výkladu právní jednání, nemůže se jeho výklad týkat pouze slovního (či písemného) projevu vưle jednajícího. Předmětem výkladu tak musí být projev vůle jako takový, bez ohledu na to, zdali k němu došlo komisivním či omisivním právním jednáním. S tím také koresponduje výklad právních jednání tak, jak je upraveno v občanském zákoníku. ${ }^{31} \mathrm{Z}$ hlediska způsobu interpretace lze patrně za nejdůležitější ustanovení považovat $\S 556$, který stanoví:

$31 \S 555$.

(1) Právní jednání se posuzuje podle svého obsahu.

(2) Má-li být určitým právním jednáním zastřeno jiné právní jednání, posoudí se podle jeho pravé povahy. $\S 556$

(1) Co je vyjádřeno slovy nebo jinak, vyloží se podle úmyslu jednajícího, byl-li takový úmysl druhé straně znám, anebo musela-li o něm vědět. Nelze-li zjistit úmysl jednajícího, přisuzuje se projevu vůle význam, jaký by mu zpravidla přikládala osoba v postavení toho, jemuž je projev vůle určen.

(2) Př́i výkladu projevu vůle se přihlédne $\mathrm{k}$ praxi zavedené mezi stranami v právním styku, $\mathrm{k}$ tomu, co právnímu jednání předcházelo, i k tomu, jak strany následně daly najevo, jaký obsah a význam právnímu jednání přikládají.

$\S 557$

Připouští-li použitý výraz různý výklad, vyloží se v pochybnostech k tíži toho, kdo výrazu použil jako první.

$\S 558$

(1) V právním styku s podnikatelem se výrazu připouštějícímu různý výklad přisoudí význam, jaký má $\mathrm{v}$ takovém styku pravidelně. Není-li však druhá strana podnikatelem, musí ten, kdo se toho dovolává, prokázat, že druhé straně musel být takový význam znám.

(2) V právním styku podnikatelů se přihlíži k obchodním zvyklostem zachovávaným obecně, anebo v daném odvětví, ledaže to vyloučí ujednání stran nebo zákon. Není-li jiné ujednání, platí, že obchodní zvyklost má přednost před ustanovením zákona, jež nemá donucující účinky, jinak se může podnikatel zvyklosti dovolat, prokáže-li, že druhá strana určitou zvyklost musela znát a s postupem podle ní byla srozuměna. 
„(1) Co je vyjádřeno slovy nebo jinak, vyloží se podle úmyslu jednajícího, byl-li takový úmysl druhé straně znám, anebo musela-li o něm vědět. Nelze-li zjistit úmysl jednajicího, prisuzuje se projevu vi̊le význam, jaký by mu zpravidla přikládala osoba $v$ postaveni toho, jemuz̆je projev vůle určen.

(2) Při výkladu projevu vůle se přihlédne k praxi zavedené mezi stranami v právním styku, $k$ tomu, co právnímu jednání předcházelo, i k tomu, jak strany následně daly najevo, jaký obsah a význam právnímu jednáni prikládaji..“

$\mathrm{Z}$ dotyčného ustanovení myslím celkem nepochybně plyne, že hlavní kritérium pro výklad představuje úmysl jednajícího. Avšak k tomu, aby mohlo být určité jednání vyloženo podle úmyslu jednajícího, musí být především patrné, k čemu tento úmysl - tedy to, co jednající chtěl - vlastně směřovalo. Úmysl jednajícího tedy nutně předpokládá odpověd' na otázku, jakého cíle mělo dotyčné právní jednání dosáhnout. Z § 556 však dále plyne, že není rozhodné, jaký cíl by snad plynul z izolovaného výkladu projevu (vůle) jednajícího, důležité je, k jakému cíli směřoval úmysl jednajícího. V okamžiku, kdy by nastal rozpor mezi projevem vůle a skutečným úmyslem jednajícího, „byl-li takový úmysl druhé straně znám, anebo musela-li o něm vědět", pak bude mít přednost úmysl jednajícího bez ohledu na tento projev.

Z hlediska použití výkladových metod $\mathrm{z}$ toho lze učinit několik závěrů. Především: jazykový, logický a systematický výklad není východiskem pro výklad právního jednání - jednak proto, že právní jednání nemusí být vždy vyjádřeno jen slovy, a zároveň také proto, že pro výklad není důležitý projev vůle jednajícího, nýbrž jeho „,úmysl“. Jestliže je úmysl jednajícího - tedy cíl, ke kterému toto jednání podle úmyslu jednajícího směřuje - základním kritériem výkladu, potom to musí znamenat, že pro výklad právních jednání je východiskem teleologický výklad.

Zároveň je však třeba vzít na vědomí skutečnost, na kterou výslovně upozornila Kateřina Ronovská a Bohumil Havel ${ }^{32}$ - že totiž není právní jednání jako právní jednání. Povaha, resp. druh právního jednání totiž může hrát roli jak pro pořadí interpretačních metod, tak také pro jejich význam. Kateřina Ronovská a Bohumil Havel správně zdůrazňují odlišnost zakladatelských právních jednání, která mají vždy písemnou formu a ze své podstaty působí nejen vưči účastníkům zakladatelského právního jednání, nýbrž vůči všem, kteří by potenciálně $\mathrm{k}$ takovému jednání mohli přistoupit. Zakladatelské právní jednání se tak mnohem spíše než „pouhé“ smlouvě podobá právnímu předpisu. Proto lze také přisvědčit jejich názoru, že „objektivizujicí výklad (tj. výklad analogický výkladu právního předpisu pozn. K. B.) je představitelný předevšim u statutárnich ujednáni obsažených $v$ zakladatelských právnich jednánich zejména kapitálových obchodnich společností, která tvoři jakousi jejich ,ústavu'se značnými , vnějšimi efekty'. Jsou to v zásadè ujednání, která zpravidla kogentně požaduje zákon a která zároveñ mají vliv na postavení korporace jako samostatné osoby v právním smyslu“.33

Způsob výkladu, který je analogický výkladu právního předpisu, se v př́padě zakladatelského právního jednání může projevit i v celkem běžné situaci, kdy se do zakladatelského právního jednání inkorporují dispozitivní ustanovení zákona. V takovém

32 RONOVSKÁ, K. - HAVEL, B. Povaha a pravidla výkladu (nejen) zakladatelských právních jednání soukromých korporací. Právní rozhledy, 2016, roč. 24, č. 18, s. 611.

33 RONOVSKÁ - HAVEL, c. d., s. 611. 
případě budou tato dispozitivní ustanovení zákona vykládána jako právní předpis, tj. mimo jiné v souladu s tím, jak dotyčná dispozitivní ustanovení vykládá judikatura. ${ }^{34}$ Naopak v př́ípadě právního jednání, které zakládá běžný závazek mezi stranami (tj. např́íklad ona zmiňovaná smlouva o přepravě), bude významnější historický (nebo v souladu s Melzerovou terminologii ,subjektivně teologický“) výklad, který se bude ptát po tom, čeho chtěly strany dosáhnout. Pokud by $\mathrm{v}$ takovém prrípadě strany inkorporovaly do smlouvy dispozitivní ustanovení zákona, potom by se jejich výklad mohl odchylovat od výkladu právních předpisů podávaných judikaturou, nebot’ by výklad měl sledovat úmysl stran při uzavírání smlouvy.

Svou formou a účinky se tak zakladatelské právní jednání podstatným způsobem odlišuje např. od již zmiňované smlouvy o přepravě, která vůbec písemnou formu mít nemusí. $\mathrm{V}$ obou př́padech však můžeme, a někdy dokonce musíme přistoupit $\mathrm{k}$ interpretaci takového právního jednání. Pořadí interpretačních metod se však bude lišit. V príípadě zakladatelského právního jednání můžeme vycházet vždy prvotně z písemného projevu vůle, zatímco v př́padě běžného právního jednání budeme spiše než z textu vycházet z úmyslu, jaký právní účinek tím či oním (nonverbálním) projevem měl být dosažen. $\mathrm{Z}$ toho důvodu je vhodné odlišovat metody výkladu, tj. zejména pořadí interpretačních metod nejen mezi právními předpisy na straně jedné a právním jednáním na straně opačné, nýbrž i uvnitř kategorie právního jednání v př́padě, že půjde o právní jednání, které se svým charakterem spíše podobá obecnému právnímu předpisu než právnímu jednání mezi individuálně určenými osobami, typicky smlouvě.

\section{ZÁVĚR}

Cílem této statě bylo ukázat, $v$ čem se liší výklad právního jednání na straně jedné od interpretace ustanovení soukromoprávních předpisů na straně opačné. $\mathrm{K}$ tomu, abychom mohli uvažovat o tom, v čem se liší, bylo třeba začít u otázky, co mají společného. Co má tedy společného „právní jednání“ a „právní předpis“ - např̀. občanský zákoník? To, co mají společného, je právní povinnost, kterou nalézáme jak v př́ípadě právního jednání, tak v př́ípadě právního předpisu. Jak ukázali normativisté, tam, kde je právní povinnost, tam je také vždy právní norma. Právní předpisy však obsahují obecné a často také abstraktně formulované normy, zatímco právní jednání obsahují normy (povinnosti), které jsou konkrétní a obvykle se také vztahují na individuálně určené subjekty. V obou těchto prípadech se však jedná o normy vynutitelné státní mocí, tj. právní normy, které musí být tak či onak jazykově vyjádřeny. Právě proto přichází v obou prípadech těchto „právních norem“ v úvahu interpretace, nebot jazykové vyjádření právní normy a norma sama mohou, ale nemusí být totožné, a to bez ohledu

\footnotetext{
$34 \mathrm{~K}$ tomu viz: „Domníváme se rovněž, v reakci na koncepci doplňování mezer v neúplných smlouvách dispozitivními zákonnými pravidly, že pokud zakladatelské právní jednání do svého obsahu výslovně či implicitně vtáhne dispozitivni zákonná pravidla, nelze je vykládat jako zákon či statutární pravidla (tj. objektivně), ale je třeba je vykládat spíše jako pravidla ,doprovodná ', jako právní jednáni." RONOVSKÁ - HAVEL, c. d., s. 611 .
} 
na to, zdali se jedná o normu obecnou obsaženou v právním předpise, anebo o normu konkrétní a individuální obsaženou v právním jednání.

Z hlediska koherence práva, které zahrnuje obecné i individuální normy, je důležitá otázka, v čem se liší interpretace norem obsažených v právním jednání od interpretace norem obsažených v právních předpisech. České soukromé právo přitom obsahuje svébytná ustanovení, která se týkají jak způsobu interpretace právních předpisů, tak právního jednání. Tím se výrazným způsobem odlišuje od veřejnoprávních předpisů, kde taková ustanovení nenalézáme. Specifikum výkladu soukromoprávních předpisů tak tví právě v tom, že je normativně vymezeno platným právem. Výklad platného práva je však výrazným způsobem ovlivněn právní doktrínou, která, zejména pokud jde o interpretaci právních předpisů, není jednotná.

V zásadě lze identifikovat dva názorové proudy, které bud’to preferují text předpisu (textualismus), anebo jeho účel (intencionalismus). Oba tyto názorové proudy se výrazným způsobem projevují při výkladu interpretačních ustanovení v občanském zákoníku. $\mathrm{Z}$ toho důvodu nelze po mém soudu podat jednoznačnou odpověd' na otázku, jakým způsobem má být výklad podáván. Lze konstatovat jen to, že na to existují odchylné názory, a $\mathrm{k}$ jednomu $\mathrm{z}$ nich se přiklonit.

Jakkoliv je však význam jednotlivých interpretačních metod předmětem sporu, zřejmě všichni se shodují na pořadí použití interpretačních metod. Zjednodušeně řečeno jde o to, že právní předpis je třeba nejprve přečíst, a teprve potom je možné jej eventuálně také teleologicky vykládat. Právě v tom se zásadním způsobem liší interpretace právních předpisů od interpretace právního jednání. Právní jednání totiž často vůbec není $\mathrm{k}$ dispozici ve své písemné formě a pravděpodobně většina právních jednání probíhá nonverbálně. To také vysvětluje, proč ustanovení platného práva preferuje při výkladu právního jednání úmysl jednajících, tedy účel, ke kterému jednání směřovalo. Pokud tak porovnáme způsob použití interpretačních metod v prŕípadě, že se jedná o výklad „ustanovení zákona“, a odlišíme jej od výkladu ,právního jednání“, docházíme k diametrálně odlišnému způsobu interpretace. Jestliže je v př́ípadě interpretace zákona jazykový, systematický a logický výklad základem, na který teprve navazuje výklad teleologický, je v př́ípadě právního jednání pořadí zcela opačné. V případě právního jednání je základní výkladovou metodou výklad teleologický, přičemž jazykový, systematický a logický výklad mohou mít význam pouze proto, aby byl zjištěn úmysl jednajícího. Z toho plyne, že v prŕípadě právního jednání bude pořadí interpretačních metod odlišné od pořadí, jaké nalézáme v př́padě výkladu právních předpisů. Ani to však neplatí bez výjimky. V př́ípadě právního jednání, které se svojí formou spíše podobá právnímu předpisu, typicky zakladatelské právní jednání, bude na místě používat opačné pořadí interpretačních metod a naopak vycházet $\mathrm{z}$ textu, nikoliv účelu, který dotyčné jednání sledovalo.

Tím vším mělo být jen řečeno, že srovnání výkladu ustanovení zákona s výkladem právního jednání je možné, a nejedná se tak pojmově o dva zcela odlišné případy. Zároveň tím mělo být řečeno, že i v rámci soukromého práva nacházíme odlišné způsoby výkladu v návaznosti na to, co je předmětem výkladu. V př́ípadě, že je předmětem výkladu ustanovení zákona, je pořadí interpretačních metod převrácené oproti pořadí, kdy je předmětem výkladu právní jednání. Praktickým důsledkem takového rozlišování je 
pohled na právo jako na systém, který netvoří pouze obecné právní normy, nýbrž také právní jednání mezi individuálně určenými subjekty. Jakkoliv je však právní jednání sice formálně označeno či chápáno jako individuální, v okamžiku, kdy svými účinky působí i vůči individuálně neurčeným subjektům, jako v př́ípadě zakladatelského právního jednání, je třeba diferencovat a odlišovat. Takové právní jednání je třeba chápat materiálně a nikoliv formálně. $\mathrm{V}$ opačném př́padě by to mohlo mít za následek nikoliv systémový př́stup k právu, nýbrž jeho fragmentarizaci, resp. antisystémový výklad, který by postrádal racionální odůvodnění.

doc. JUDr. Karel Beran, Ph.D.

Právnická fakulta Univerzity Karlovy

beran@prf.cuni.cz 